\title{
Medicinal Plant Use and Health Sovereignty: Findings from the Tajik and Afghan Pamirs
}

\author{
Karim-Aly Kassam • Munira Karamkhudoeva • \\ Morgan Ruelle • Michelle Baumflek
}

Published online: 27 November 2010

(C) The Author(s) 2010. This article is published with open access at Springerlink.com

\begin{abstract}
Medicinal plants are indicators of indigenous knowledge in the context of political volatility and sociocultural and ecological change in the Pamir Mountains of Afghanistan and Tajikistan. Medicinal plants are the primary health care option in this region of Central Asia. The main objective of this paper is to demonstrate that medicinal plants contribute to health security and sovereignty in a time of instability. We illustrate the nutritional as well as medicinal significance of plants in the daily lives of villagers. Based on over a decade and half of research related to resilience and livelihood security, we present plant uses in the context of mountain communities. Villagers identified over 58 cultivated and noncultivated plants and described 310 distinct uses within 63 categories of treatment and prevention. Presence of knowledge about medicinal plants is directly connected to their use.
\end{abstract}

Keywords Afghanistan - Indigenous knowledge ·

Food security · Food sovereignty · Health security .

Health sovereignty $\cdot$ Medicinal plants $\cdot$ Pamir Mountains .

Tajikistan

K.-A. Kassam $(\bowtie) \cdot$ M. Ruelle $\cdot$ M. Baumflek

Cornell University,

Ithaca, NY, USA

e-mail:ksk28@cornell.edu

M. Karamkhudoeva

Pamir Biological Institute,

Academy of Sciences of the Republic of Tajikistan,

Khorog, Republic of Tajikistan

\section{Introduction}

Indigenous peoples have the right to their traditional medicines and to maintain their health practices, including the conservation of their vital medicinal plants, animals and minerals. Indigenous individuals also have the right to access, without any discrimination, to all social and health services (United Nations Declaration on the Rights of Indigenous Peoples, 2008, Article 24, Section 1).

The notions of health security and health sovereignty are analogous to the discussion of food security and food sovereignty. Unlike food security, which suggests access to food to meet minimum nutritional needs, food sovereignty encompasses the right and ability of individuals and groups to choose their own food based on the socio-cultural and ecological systems they inhabit (Mousseau 2005; Kassam 2010; Nabhan 2009; Windfuhr and Jonsén 2005). The idea of health sovereignty includes the ability to choose medicines that are socio-culturally and ecologically appropriate thereby providing practical, reliable, and contextuallyrelevant health care options (Kickbush 2000; Smith 2006). Denial of self-determination over food and medicine is a repudiation of fundamental rights of autonomy as guaranteed by Article 24 Section 1 of the UN Deceleration on the Rights of Indigenous Peoples (quoted above).

The significance of medicinal plant use to food and health sovereignty is amplified under conditions of sociocultural and ecological change in the Pamir Mountains of Afghanistan and Tajikistan. The peoples of this region, whose history is associated with the Silk Road, have been at the vanguard of violations on their sovereignty in the form of imperial machinations of the British Empire and 
Russia, and subsequent cold war alliances between the West and the Eastern Bloc countries. More recently, civil unrest during the 1990s in Tajikistan and a 30-year global war localized to Afghanistan has contributed to regional instability. Under these conditions, food and health systems are compromised and the threat of famine is ever-present. Given the collapse of the command economy in Tajikistan and continued political and social instability resulting from war in Afghanistan, locally available foods and medicines are important options for food and health sovereignty.

Indigenous knowledge of medicinal plant use is contextspecific as it is related to, and contained within, a group of people who live in a defined geographic region-in this case the Pamir Mountains of Central Asia. Knowledge for this context is derived from the web of interactions between humans, plants, animals, natural forces, and land forms. Therefore, social, ethical, and spiritual relationships also have an ecological foundation. Context-specific knowledge about soil variation, temperature, water, characteristics of local plants, and seasonal conditions accumulated over generations enables medicinal plant users in the Afghan and Tajik Pamirs to sustain dynamic relationships within their habitat (Kassam 2009a). Research consistently indicates that agrobiodiversity based on indigenous farmer knowledge contributes to food sovereignty (Rerkasem et al. 2002). Similarly, medicinal plant knowledge contributes to health sovereignty, in which local peoples have meaningful options in their social and ecological systems.

Indigenous knowledge of medicinal plant use in the Pamir Mountains may be threatened by continued sociopolitical instability, climatic change, and the impacts of the globalized market system (Voeks and Leony 2004). For instance, under the Soviet command-economy, communities in Tajikistan were forced into industrial agriculture, resulting in the losses of valuable ecological knowledge and a diversity of seeds which had been adapted for local cultivation. Similarly, the intervention of institutional medical systems connected to the profit-driven international pharmaceutical industry might compromise long term retention of medicinal plant use. We do not suggest that there is no role for 'western' medicine and hospitals in these regions, but such facilities are hard to sustain with limited resources and may not be easily accessible in terms of both cost and distance for the majority of the rural inhabitants of this region (AKF-T 2004; Bartlett et al. 2005).

Our objective is to demonstrate indigenous human ecological knowledge related to medicinal plants. After describing the research approach, we examine indigenous knowledge of plant diversity, plant use categories with respect to health sovereignty, the notion that food is medicine, seasonal availability and storage of plants, and conclude with suggestions for further research on medic- inal plants in the Pamir Mountains of Afghanistan and Tajikistan.

\section{Methodology}

\section{Data Collection}

In East and South Asia, considerable scholarship has been devoted to traditional systems of medicine (Patwardhan et al. 2005; Patwardhan and Mashelkar 2009; Shankar 2001; Shankar et al. 2007; Shukla and Gardner 2006; Shukla and Sinclair 2009; WHO 2002). Similarly, there is a significant corpus of literature related to medicinal plants in Central Asia. In addition to Russian, other European, and Central Asian scholars (Губанова, Киселёва, и Новиков 1987; Hooper 1937; Кисляков and Писарчик 1970; Наврузшоев 1998; Нуралиев 1989; Sezik et al. 2004; Соколов и Замотаев 1984), older manuscripts in Persian are in existence. However, this literature is largely unavailable from libraries in Tajikistan because they have been pilfered after the collapse of the Soviet Union and there are limited resources to rebuild collections resulting from economic decline. This literature is also unavailable in war-torn Afghanistan. Works that are extant remain largely with private individuals and organizations and are not easily accessible. As the purpose of this work is to discuss medicinal plant use in relation to health sovereignty, and given the lack of accessibility to secondary sources specific to the Pamir Mountains of Afghanistan and Tajikistan, primary data was gathered through interviews with villagers living in the region.

Therefore, this paper represents cumulatively over a decade of fieldwork by the first and second authors with villagers living at a range of elevations in valleys throughout the Gorno Badakhshan Autonomous Oblast (GBAO) of Tajikstan and the Badakhshan Province of Afghanistan (see Fig. 1). The first and second authors have documented knowledge of medicinal plants in conjunction with research on other topics. ${ }^{1}$ Semi-structured interviews were conducted in 114 villages from July 1999 to November of 2009. These interviews provide methodological flexibility to compile information from dialogue with individuals or small groups (Butler et al. 1995; Gibbs 2003). Villagers were invited to participate if they: 1) said they had knowledge about medicinal plants, or 2) were acknowledged by others in the village to have such knowledge. Some interviewees participated in both individual and small group interviews. In order to assess

\footnotetext{
${ }^{1}$ The first author's research is largely related to livelihood security (Kassam 2009a, 2010). The second author's research focused on cultivated plant pests and diseases.
} 


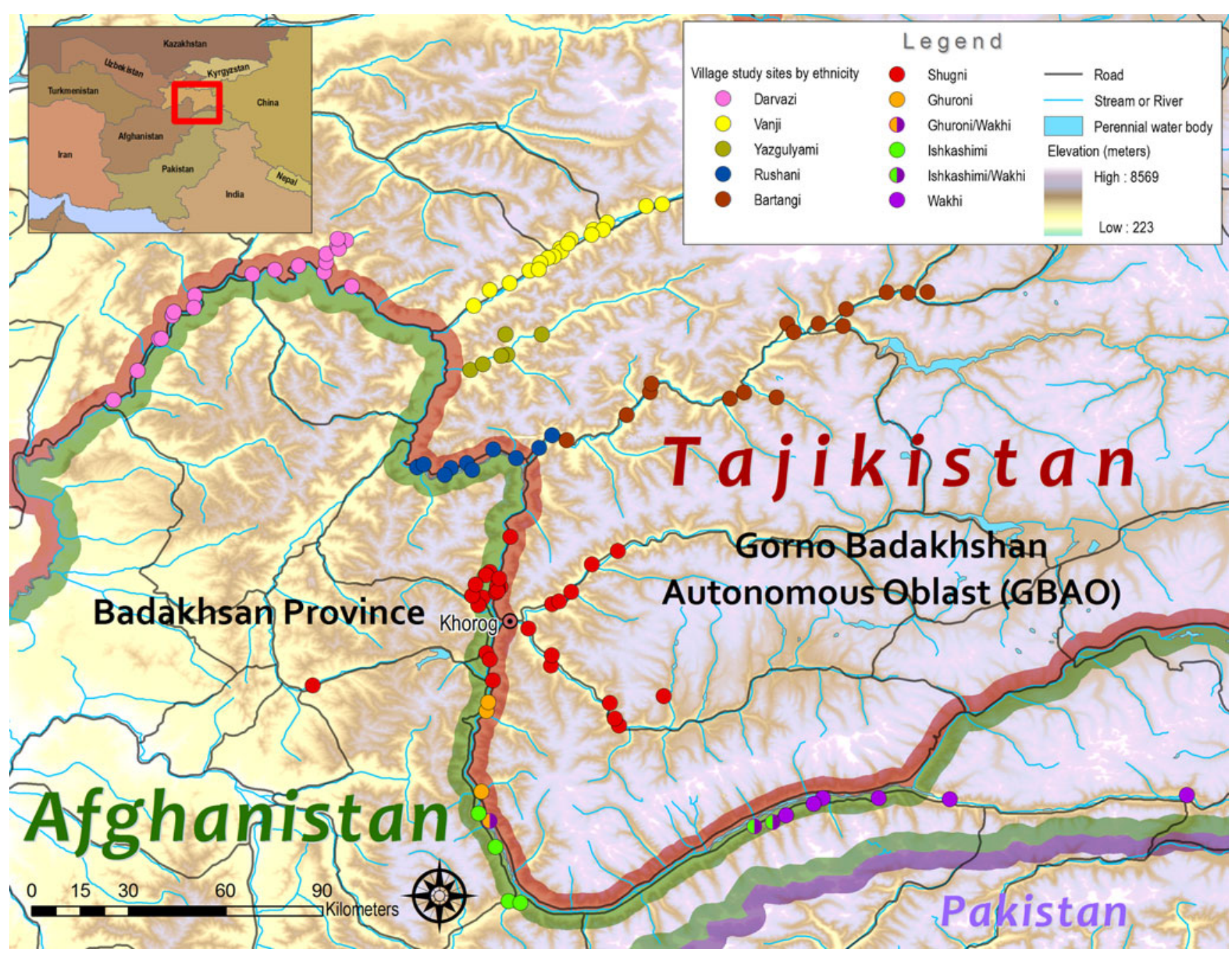

Fig. 1 Map of research area

diversity of plant knowledge and use, interview questions included: 1) Which plants do you use? 2) How do you use this plant? 3) Do you use this plant fresh or dried? 4) Which parts of this plant do you use? 5) When do you collect this plant? and 6) How long can you store this plant? While indigenous knowledge of opium use as medicine is important, for reasons of security it was avoided during our research and requires further investigation.

Karamkhudoeva is Rushani and Shugni from the Pamir Mountains of Tajikistan, and learned about medicinal plants from family and friends. Her familiarity with plant use in the Pamirs allowed her to deeply probe the indigenous knowledge compiled during research. From 1999 to 2009, Karamkhudoeva conducted small group interviews (5 to 10 individuals) with 340 individuals (180 men and 160 women) ranging from 11 to 95 years of age. Karamkhudoeva conducted individual interviews with 150 men and 130 women. From 2006 to 2009, Kassam conducted semistructured interviews with small groups and individuals in
14 villages. Interviews were conducted with 294 individuals ranging in age from 17 to 75 , with the majority of participants aged 35 to 55 . Most of these interviews were conducted with small groups of either men or women, but some mixed-gender groups also occurred spontaneously.

A major strength of small group interviews facilitated by the researchers is that they enabled discussion among participants about differences in plant use. Although small group interviews provided substantial information, the approach was limited by several methodological constraints: 1) men and women appeared hesitant to provide genderspecific plant knowledge when they were interviewed together, 2) annual crop harvests at the time of research may have reduced participation, 3) some individuals may have dominated small group interactions, and 4) small group interviews did not provide opportunities to walk and observe plants in order to engage knowledge of their use.

An adaptive interview process was employed to overcome the constraints noted above. To complement small 
group interviews, individual interviews included the similar questions as the group interviews, but responses provided additional insights because 1) participants provided genderspecific knowledge 2) individual schedules were easier to accommodate, 3) the heterogeneity of knowledge among individuals was no longer silenced by group dynamics, and 4) most interviews were conducted outside to identify and discuss plant uses.

\section{Analytical Approach}

Plant uses described during small group and individual interviews were systematized according to plant usage categories developed by Moerman (1998: 19-23). Moerman developed these groupings based on use of plants among indigenous Americans. In cases where a particular use of a plant could be assigned to more than one category, the most specific category was used; i.e., no description of use was assigned to more than one category. Modifications and additions were made to Moerman's categories in order to reflect the context specificity of medicinal uses described by indigenous participants from the Pamir Mountains of Afghanistan and Tajikistan. Hence, three categories were modified and 15 new medicinal plant uses were added for treatment and prevention reflecting the context of the Pamir Mountains.

The application of plant usage categories, while in some ways an imposition of the researchers' own logic, is an opportunity to examine medicinal plants per function rather than per species. This analysis also allows for comparison with current trends in the institutional health care system to evaluate the potential for medicinal plants to improve human health. Furthermore, data were analyzed with respect to how the plant was obtained - gathered or cultivated, parts used, seasonal availability, and storage - to relate these processes to health sovereignty.

\section{Results and Analysis}

\section{Pamiri Knowledge of Plant Diversity}

During individual and small group interviews, participants described the use of at least 58 plants. The researchers were able to identify 54 botanical species and 4 genera corresponding to local identifications (see Table 1). Participants recognize different types within three of the four genera (mints-Mentha sp., hawthorns-Crataegus sp., and apples-Malus sp.), but researchers found it difficult to accurately identify corresponding species or varieties. Twenty-seven botanical families are represented, but five families (ten species in Asteraceae, five species and one genus in Lamiaceae, five species in Apiaceae, three species and two genera in Rosaceae, and four species in Fabaceae), account for over half of the plants described. This list is not exhaustive as other villagers in the Pamir region, not interviewed in this study, may know how to use other plants as medicine.

\section{Plant Use Categories and Health Sovereignty}

Our analysis of interview data reveals 310 distinct uses of 58 plants in 63 categories of treatment and prevention (see Table 2). The largest plant usage categories (in terms of the number of plants that fall within them) are: gastro-intestinal aids (31 plants), dermatological aids (18 plants), kidney aids (15 plants), analgesics (13 plants), liver aids (13 plants), and hypotensives (ten plants). Frequency of specific medicinal plant use categories correspond with the most common causes for hospital visits in the GBAO of Tajikistan $^{2}$ (AKF-T 2008, Table 6.3.1). The most common reasons are: acute respiratory infections (which correspond to seven pulmonary aids and seven respiratory aids), digestive organ diseases (which correspond to 31 gastrointestinal aids), heart problems (which correspond to eight heart medicines), injuries/trauma (which correspond to 13 analgesics, six orthopedic aids, and eight treatments for cuts, bruises and wounds) and kidney diseases (which correspond to 15 kidney aids). This correspondence implies 1) that the diversity of knowledge within a specific plant usage category (as demonstrated by number of plants used for the same purpose) is indicative of the frequency of related medical conditions in the Pamirs, and 2) that medicinal plant knowledge is highly relevant to the health sovereignty of the Pamirs.

Plant diversity and functional redundancy of use contributes to the resilience of Pamiri people. Resilience is the capacity of social and ecological systems to absorb disturbance and still retain their basic function and structure (Chapin et al. 2004; Holling 1973; Folke et al. 2002; Folke 2006; Walker and Salt 2006; Miller et al. 2008). The ability to use many different plants to treat a specific medical concern creates functional redundancy and facilitates resilience by increasing the likelihood for substitution if a particular plant is unavailable. For example villagers described the overharvest of Rhodiola gelida (zarchoy) after it became popularized as an energy enhancer. Six other plants known to the communities as energy enhancers (see Table 2, "strengtheners") are used instead. The diversity of treatment possibilities also contributes to health sovereignty by enabling individuals to choose the most appropriate treatments.

\footnotetext{
${ }^{2}$ We were unable to find parallel health statistics for the Badakhshan province of Afghanistan.
} 
Table 1 Shugni, Latin, and English names of medicinal plants discussed by Pamiri villagers

\begin{tabular}{|c|c|c|}
\hline Shugni ${ }^{1}$ or other local name & Botanical Name & Common English name \\
\hline amojak & Ephedra intermedia Schrenk ex Mey. & none \\
\hline anjir & Ficus carica L. & fig \\
\hline anor & Punica granatum $\mathrm{L}$. & pomegranate \\
\hline bobtsuthmak & Scariola orientalis (Boiss.) Sojak & none \\
\hline charmak, bobak & Bunium badachschanicum Kamelin & none, black cumin genus \\
\hline chidghints & Urtica dioica L. & stinging nettle \\
\hline choywox̌ak & Hypericum perforatum $\mathrm{L}$. & St. John's-wort \\
\hline galshuth & Hippophae rhamnoides L. & common sea-buckthorn \\
\hline ghithts (Shugni), dulona (Tajik) & Crataegus sp. & hawthorn \\
\hline guli, x̌ameshabahor & Calendula officinalis $\mathrm{L}$. & pot-marigold \\
\hline jambilak & Ziziphora pamiroalaica Juz. ex Nevski & none \\
\hline khidarmax̆ & Vicia faba L. & fava bean \\
\hline kilak bartangi & Triticum aestivum $\mathrm{L}$. & wheat \\
\hline kilo (Shugni), kadu (Tajik) & Cucurbita pepo L. & pumpkin, squash \\
\hline kirux̆ & Ferula jaeschkeana Vatke & none \\
\hline kiznach & Cichorium intybus $\mathrm{L}$. & chicory \\
\hline kuyi pudina & Origanum vulgare $\mathrm{L}$. & wild marjoram \\
\hline limon & Citrus limon (L.) Burm. & lemon \\
\hline lůng & Eremostachys speciosa var. schugnanicaPopov & none \\
\hline mukholifka & Leptorhabdos virgata Benth. & none \\
\hline mun & Malus sp. & apple \\
\hline muthq & Glycyrrhiza glabra L. & licorice \\
\hline nosh & Prunus armeniaca L. & apricot \\
\hline oftobparast & Helianthus annuus L. & sunflower \\
\hline ragakwox̌ & Plantago major L. & plantain \\
\hline shaftal & Trifolium pratense L. & red clover \\
\hline shalkha & Rumex confertus Willdenow & Asiatic dock \\
\hline shirghorjak & Melilotus officinalis L. & yellow sweet-clover \\
\hline shirgulak & Taraxacum officinale Weber & dandelion \\
\hline shirizm & Ribes villosum Wall. & none, currant genus \\
\hline shitorthk & Rheum maximowiczii Losinsk. & none, rhubarb genus \\
\hline sidikhts & Artemisia sieversiana Ehrh. & none, wormwood genus \\
\hline sipandůna & Peganum harmala L. & harmel peganum \\
\hline sir & Allium sativum $\mathrm{L}$. & garlic \\
\hline strakhm & Anaphalis virgata Thomson & none, pearly everlasting genus \\
\hline toji khurus & Amaranthus sp? & common amaranth \\
\hline tsex̌tsak & Artemisia dracunculus L. & tarragon \\
\hline tsirovakvox̌ (Shugni), gazg (Wakhi) & Sisymbrium brassiciforme C.A. Mey. & none \\
\hline tuth & Morus alba L. & white mulberry \\
\hline varx̌ & Prangos pabularia Lindl. & none \\
\hline withn, withm & Mentha sp. & mint \\
\hline x̌ar & Rosa canina L. & dog rose \\
\hline x̌arbara & Rosa corymbifera L. & none, rose genus \\
\hline x̌arbinj & Zea mays $\mathrm{L}$. & corn, maize \\
\hline xarbit & Anethum graveolens $\mathrm{L}$. & dill \\
\hline x̌aspirukhm & Ocimum basilicum L. & sweet basil \\
\hline x̌ichifkhorth & Nepeta glutinosa Benth. & none, catnip genus \\
\hline x̌ikurang & Impatiens balsamina L. & balsam \\
\hline x̌ipex̌k & Arnebia euchroma (Royle ex Benth.) I.M. Johnston & none \\
\hline x̌itsit & Ribes janczewskii Pojarkova & none, currant genus \\
\hline zagher & Linum usitatissimum $\mathrm{L}$. & flax, linseed \\
\hline zarchoy & Rhodiola gelida Schrenk & none \\
\hline zarghůl & Berberis heterobotrys E. L. Wolf & none, barberry genus \\
\hline zarposha & Tanacetum pseudachillea C. Winkl. & none, tansy genus \\
\hline zhirmesk & Althaea officinalis $\mathrm{L}$. & marsh mallow \\
\hline zhowmisk & Polygonum coriarium Grigorjev & none \\
\hline zira & Bunium persicum B.Fedtsch. & black cumin \\
\hline zirdosk & Achillea millefolium $\mathrm{L}$. & yarrow \\
\hline
\end{tabular}

\footnotetext{
${ }^{1}$ We have privileged Shugni names in favor of other local names because they may be more widely understood.
}

${ }^{2}$ Researchers were only able to identify the genus of this plant. 
Institutional health care systems are playing an increasing role in the lives of Pamiri people. From 2004 to 2007, rates of hospitalization in the GBAO have risen from $23 \%$ to $44 \%$ (AKF-T 2008). During the same period, reported rates of selftreatment for acute diseases dropped from $32 \%$ to $17 \%$ (AKF-T 2008). If medicinal plants play a role in some portion of self-treatments in the Pamirs, lower rates of selftreatment may represent a reduction in medicinal plant use. Plant use and knowledge are mutually reinforcing (Wyndham 2010). As communities lose knowledge of medicinal plants, they lose health care options. This may have long term implications for health sovereignty. Therefore, a decision to promote knowledge of medicinal plants should not be motivated by a romantic notion that such knowledge is inherently valuable. The resilience of communities may rely on practical wisdom to use medicinal plants as an alternative to or in combination with institutional health care systems.

While hospitalization is an important option, high cost, limited access and lack of medical professionals impact the efficacy of institutional health care systems. The average cost of hospital care rose from 189 somoni in 2004 to 346 somoni in 2007, which is more than an average monthly salary in the Pamirs (AKF-T 2008; Eurasianet.org 2008). Medications make up approximately $45 \%$ of the costs of a hospital stay (AKF-T 2008). Arguably, medicinal plants can provide less expensive forms of effective treatment. Furthermore, hospitalization is not always possible, particularly in the remote mountainous province of Badakhshan, Afghanistan. In some areas of Badakhshan, access to essential medical care, such as comprehensive obstetric services, may require up to 10 days of travel by foot. Outside of major urban centers, there is a severe lack of medical care providers for women (Bartlett et al. 2005). In these situations, self-treatment may be the only option, and local knowledge of medicinal plants might save lives.

\section{Food is Medicine: Gathered and Cultivated Plants}

While this research focused on plants used as medicine, the majority of medicinal plants (62\%) are also used for food (Fig. 2a). Any distinction between plants as food and medicine can be problematic, since many plant uses are known to provide both nutritive and other medicinal benefits simultaneously (Sundriyal and Sundriyal 2001). In some cases, Pamiri villagers do not distinguish between the use of plants as food and medicine. For example, villagers explained that regular consumption of apricots can treat and prevent high blood pressure and heart disease. These uses indicate a perception that "food is medicine", which is prevalent among indigenous communities globally (Etkin and Ross 1982; LaDuke 2005; LaDuke et al. 2010). In other cases, villagers describe distinct uses of the same plants as food and as medicine. Sometimes a different part of the plant is used for medicine than for food. For example, flour made from milling wheat grains is used for bread, but a decoction made from wheat stems and honey is drunk to relieve the inflammation of the upper respiratory tract or cure a deep cough. In other instances, the same part of a plant is prepared differently in order to produce food or medicine. The leaves, stems, and seeds of Anethum graveolens (x̌arbit), for example, are chopped and added fresh to flavor many foods, but are also prepared as a decoction to treat pain in the spine, kidneys, and bladder. These distinctions between food and other medicinal uses of plants are similar to findings from Hausaland in northern Nigeria (Etkin and Ross 1994). Finally, a significant number of plants are used as medicine but not as food. Therefore, in the case of indigenous knowledge in the Pamirs, we find that food is generally considered medicine (since nutrients are fundamental to human health), but not all medicines are considered food. Medicinal plants as a category include most (if not all) food plants, but foods and other medicines may be distinguished by their use and perceived benefits.

Like food, plants used for medicine are cultivated and gathered. Thirty-three percent (19 of 58) of plants are both cultivated and gathered (see Fig. 2b). In these cases, villagers grow plants in their fields and access distinct populations in non-cultivated areas, such as pastures and mountainsides. Some non-cultivated plants are transplanted into gardens or grafted onto cultivated plants. These practices may contribute to genetic diversity within cultivated populations, and facilitate ongoing processes of domestication (Nabhan 2009; Vavilov 1926, 1951, 1957, 1992, 1997). On the other hand, villagers continue to gather many plants that they also grow. In other parts of the world, healers believe that non-cultivated plants are more potent than cultivated populations of the same plant (Shukla and Sinclair 2009). In the Pamirs, $77 \%$ of strictly medicinal plants (those that are not also used for food) are gathered rather than cultivated (see Table 3). This pattern may also indicate similar beliefs in the efficacy of treatments derived from non-cultivated plants.

Returning to the role of medicinal plants in nourishment, the notion that food is medicine ${ }^{3}$ is key to addressing malnutrition, which is a serious and prevalent condition in the Pamir region (AKF-T 2008). In Afghan Badakhshan, malnutrition contributed to the highest maternal mortality rate ever reported (2005), 6,500 maternal deaths per

\footnotetext{
${ }^{3}$ The etymology of the word "medicine" reveals that it is defined in relation to disease, whether used for treatment or prevention (OED 2010). Diseases are likewise recognized based on specific cultural values and norms. In contexts where diet-related conditions are considered diseases, food is an important category of medicine to provide effective treatment and prevention.
} 
Table 2 Uses of medicinal plants by category of treatment and prevention

Category of medicinal use Number of plants Percent of all uses

\begin{tabular}{|c|c|c|}
\hline Gastrointestinal aid & 31 & $10.0 \%$ \\
\hline Dermatological aid & 18 & $5.8 \%$ \\
\hline Kidney aid & 15 & $4.8 \%$ \\
\hline Analgesic $^{\mathrm{a}}$ & 13 & $4.2 \%$ \\
\hline Liver aid & 13 & $4.2 \%$ \\
\hline Hypotensive & 10 & $3.2 \%$ \\
\hline Cough medicine & 8 & $2.6 \%$ \\
\hline Cuts, bruises, and wounds ${ }^{\mathrm{b}}$ & 8 & $2.6 \%$ \\
\hline Dietary aid & 8 & $2.6 \%$ \\
\hline Heart medicine & 8 & $2.6 \%$ \\
\hline Oral aid & 8 & $2.6 \%$ \\
\hline Urinary aid & 8 & $2.6 \%$ \\
\hline Blood medicine & 7 & $2.3 \%$ \\
\hline Pulmonary aid & 7 & $2.3 \%$ \\
\hline Respiratory aid & 7 & $2.3 \%$ \\
\hline Strengthener & 7 & $2.3 \%$ \\
\hline Antidiarrheal & 6 & $1.9 \%$ \\
\hline Diuretic & 6 & $1.9 \%$ \\
\hline Laxative & 6 & $1.9 \%$ \\
\hline Orthopedic aid & 6 & $1.9 \%$ \\
\hline Toothache remedy & 6 & $1.9 \%$ \\
\hline Antirheumetic & 5 & $1.6 \%$ \\
\hline Burn aid & 5 & $1.6 \%$ \\
\hline Dysentery medicine $^{\mathrm{d}}$ & 5 & $1.6 \%$ \\
\hline Throat aid & 5 & $1.6 \%$ \\
\hline Vitamins ${ }^{\mathrm{e}}$ & 5 & $1.6 \%$ \\
\hline Diabetes medicine $^{\mathrm{f}}$ & 4 & $1.3 \%$ \\
\hline Febrifuge & 4 & $1.3 \%$ \\
\hline Gall bladder aid ${ }^{\mathrm{g}}$ & 4 & $1.3 \%$ \\
\hline Gynecological aid & 4 & $1.3 \%$ \\
\hline Sedative & 4 & $1.3 \%$ \\
\hline Thirst quencher ${ }^{\mathrm{h}}$ & 4 & $1.3 \%$ \\
\hline Adjuvant & 3 & $1.0 \%$ \\
\hline Cathartic & 3 & $1.0 \%$ \\
\hline Cold remedy & 3 & $1.0 \%$ \\
\hline Eye medicine & 3 & $1.0 \%$ \\
\hline Purifying smoke ${ }^{\mathrm{i}}$ & 3 & $1.0 \%$ \\
\hline Tuberculosis remedy & 3 & $1.0 \%$ \\
\hline Abortifacient & 2 & $0.6 \%$ \\
\hline Bite remedy ${ }^{j}$ & 2 & $0.6 \%$ \\
\hline Ear medicine & 2 & $0.6 \%$ \\
\hline Expectorant & 2 & $0.6 \%$ \\
\hline Hemostat & 2 & $0.6 \%$ \\
\hline Insect repellant ${ }^{\mathrm{k}}$ & 2 & $0.6 \%$ \\
\hline Lactation aid ${ }^{1}$ & 2 & $0.6 \%$ \\
\hline Pediatric aid & 2 & $0.6 \%$ \\
\hline Preventative medicine & 2 & $0.6 \%$ \\
\hline Psychological aid & 2 & $0.6 \%$ \\
\hline
\end{tabular}

Table 2 (continued)

Category of medicinal use Number of plants Percent of all uses

\begin{tabular}{lrr}
\hline Reproductive aid & 2 & $0.6 \%$ \\
Stimulant & 2 & $0.6 \%$ \\
Antihemorrhagic & 1 & $0.3 \%$ \\
Disinfectant & 1 & $0.3 \%$ \\
Emetic & 1 & $0.3 \%$ \\
Gland medicine $^{\text {Hernia medicine }}{ }^{\mathrm{m}}$ & 1 & $0.3 \%$ \\
Malaria medicine $^{\mathrm{n}}$ & 1 & $0.3 \%$ \\
Memory aid $^{\mathrm{o}}$ & 1 & $0.3 \%$ \\
Mitigate effects of alcohol $^{\mathrm{p}}$ & 1 & $0.3 \%$ \\
Narcotic $^{\text {Poultice }}$ & 1 & $0.3 \%$ \\
Spleen aid $^{\mathrm{q}}$ & 1 & $0.3 \%$ \\
Sunstroke medicine $^{\mathrm{r}}$ & 1 & $0.3 \%$ \\
Vertigo medicine $^{\text {Total plant uses }}$ & 1 & $0.3 \%$ \\
& 1 & $0.3 \%$ \\
\hline
\end{tabular}

aModified from Moerman's "Analgesic" to include all plants used to reduce inflammation

${ }^{\mathrm{b}}$ Medicinal plants used to treat minor cuts, bruises, and more serious wounds

${ }^{\mathrm{c}}$ Modified from Moerman's "Burn Dressing" to include medicinal plants used internally in the treatment of burns

${ }^{\mathrm{d}}$ Medicinal plants that treat dysentery

${ }^{\mathrm{e}}$ Medicinal plants consumed as a source of vitamins

${ }^{\mathrm{f}}$ Medicinal plants that treat diabetes

${ }^{\mathrm{g}}$ Medicinal plants that treat diseases of the gall bladder, including gallstones

${ }^{\mathrm{h}}$ Medicinal plants that reduce the sensation of thirst

${ }^{\mathrm{i}}$ Medicinal plants burned to purify or cleanse one's surroundings

${ }^{j}$ Modified from Moerman's "Snakebite Remedy" to include treatment of scorpion bites

${ }^{\mathrm{k}}$ Medicinal plants used to repel disease-carrying insects

${ }^{1}$ Medicinal plants used to increase lactation for breastfeeding

${ }^{\mathrm{m}}$ Medicinal plants that treat hernias

${ }^{\mathrm{n}}$ Medicinal plants that treat malaria

${ }^{\circ}$ Medicinal plants that enhance memory

${ }^{\mathrm{p}}$ Medicinal plants used to mitigate the effects of excessive alcohol consumption

${ }^{\mathrm{q}}$ Medicinal plants that treat diseases of the spleen

${ }^{\mathrm{r}}$ Medicinal plants that treat sunstroke

100,000 live births (Smith and Burnham 2005). A 2007 household survey conducted by the Aga Khan Foundation in the GBAO reveals that $32 \%$ of children under the age of five are classified as chronically malnourished. Anemia is also epidemic in the population: within the household survey, $81 \%$ of children and $99.6 \%$ of women were found to be anemic to some degree. In addressing malnutrition and other diet-related diseases, including anemia, a distinction between food and medicine is not relevant. Many 
a

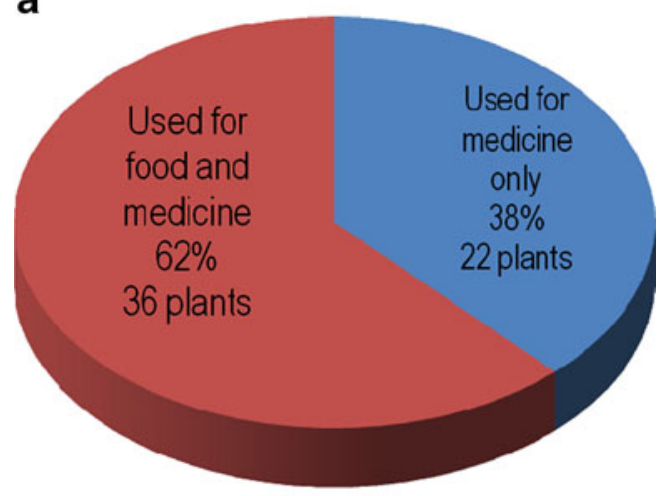

b

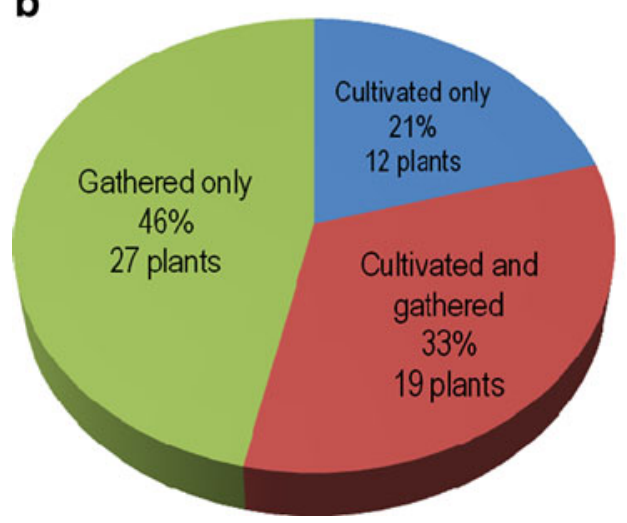

Fig. 2 a Use of plants as food and/or medicine. b Method used to obtain plants

medicinal plants (used as food) can reduce malnutrition, and villagers described specific uses of medicinal plants to treat and prevent anemia. Thus, medicinal plants that are food can play a key role in improving human health where diet-related diseases ${ }^{4}$ are prevalent.

\section{Seasonal Availability, Preservation, and Storage}

Medicinal plants need to be collected at specific times of the year. All plants described by participants are gathered or harvested $^{5}$ in late spring through autumn, with the highest number of medicinal plants available in July, August, and September (see Fig. 3). The availability of plants range from 1 to 3 months, and the average availability is 1.17 months (standard deviation 0.53 ). The largest variety of non-cultivated plants is gathered in July, while the majority of cultivated medicinal plants are harvested in September. These two peaks of plant collection activity

\footnotetext{
${ }^{4}$ Based on research in Nigeria, Etkin (2003) has shown that communities have developed adaptive systems to use foods in response to specific diseases, even when those diseases (such as malaria) are not widely recognized as "diet-related".

${ }^{5}$ For the purposes of this paper, we use the term "gathered" to refer to collection of non-cultivated plants and the term "harvested" to refer to collection of cultivated plants.
}

represent a differentiation in the timing of gathering noncultivated plants versus harvesting cultivated plants. This difference may indicate time allocation by participants (there is less time to gather non-cultivated plants during the harvest season), and may also reflect the reality of species availability throughout the year.

The timing of collection also relates to parts of the plants used by participants, since flowers and leaves are available earlier in the year than fruits and seeds. Vegetative and flowering parts available earlier in the year have a greater number of uses than fruiting parts (see Fig. 4). In some cases, the entire plant is employed in preparing medicine as well as various parts in combination. As in other mountain regions (Boesi and Cardi 2006), Pamiri villagers use plants in combination with other organic medicinal substances (e.g., other plants, honey, minerals, and animal fat). Constraints in the temporal availability of plants and the fact that no medicinal plants are available from December through April means that medicinal plants must be stored for later use.

Many medicinal plants described by participants are used only fresh ( $36 \%$ or 21 of 58 plants), but some of these can be stored in root cellars for several months. Nineteen percent or 11 plants are used only dried, and $45 \%$ or 26 plants are used both fresh and dried. Therefore, 64\% of medicinal plants can be dried to increase their storage time (37 of 58 plants, see Fig. 5).

The maximum storage lengths of medicinal plants range from less than one year to more than six years, with the majority of plants storable for up to two years (see Fig. 6).

Analysis of estimated maximum storage lengths reveals that participants' report shorter maximum storage lengths for medicinal plants that are used fresh than for those plants that are used dried (see Fig. 7). This relationship, although not a statistically significant correlation, indicates that the processes of drying (often in direct sun or under an awning) and storing are key elements of health sovereignty. Drying and storing plants allows Pamir communities to have the majority of their medicines available year-round. The long storage length of certain plants allows for a certain degree of flexibility in timing of use, implying capacity for health sovereignty. The effects of environmental degradation and the impacts of climate change, including increasing uncertainty in the ecosystem processes and more frequent cycles of unfavorable weather may be mitigated by these storage processes. Stores of medicinal plants may also play an important role during social instability, periods of civil unrest or war.

\section{Situated Plant Knowledge}

Presence of knowledge about medicinal plants is directly related to their use. The loss of specific plant knowledge due to lack of regular use is observed in the villages of 
Table 3 Relationship between plant uses and methods used to obtain plants

\begin{tabular}{llll}
\hline & Food and medicine & Medicine only & Total \\
\hline Cultivated only & 10 species & 2 species & 12 species \\
Cultivated and gathered & 16 species & 3 species & 19 species \\
Gathered only & 10 species & 17 species & 27 species \\
Total & 36 species & 22 species & 58 species \\
\hline
\end{tabular}

Savnob and Basid in Tajikistan. When these regions switched from self-sustaining agricultural production to a command economy, they consequently lost the seeds to grow watermelon. Along with the seeds, the know-how for growing watermelon in their specific montane habitat was also lost (Kassam 2009a). Wyndham (2010) observed that children in Rarámuri (Tarahumara) communities in Chihuahua, Mexico, were more likely to know the use of a medicinal plant than its local name. In the former Soviet Republics, learning about medicinal plants may skip a generation of people who did not use these plants during the Soviet period (Kassam 2009b). Indigenous knowledge was not privileged in the centralized economy. Our research in Tajikistan found instances where youth knew more specific uses of medicinal plants than their parents. These children said they learned about medicinal plants from their grandparents while they worked in high mountain pastures. This learning results from active engagement with one's habitat, which is increasingly valued for survival and good health after the collapse of the command economy.

Ecological knowledge is not only embedded in people's minds, but also in their relations within their habitat. For example, Kassam interviewed a farmer in the village of Chandin (Tajikistan) who had been a school teacher before the civil war that ensued after the collapse of the Soviet Union. When asked about medicinal plants, he insisted that he knew nothing about them and that we should seek such information from village experts on plants. The resistance to describing plant usages did not relate to the teacher-cum-farmer's hesitance to share knowledge, as he was genuinely helpful and welcoming, but how knowledge manifests itself in day-to-day human ecological interactions. Shortly afterwards, as we went for a walk to a nearby sacred site, the same individual identified nine medicinal plants and detailed their uses. The environment acts in relation to the mind to form useful knowledge. This example illustrates that memories are formed through the functioning of sensory perception and generated and forged by the movement of a person in the course of daily activities. Ecological knowledge is experienced in one's habitat. It is not book learning, but learning from the experience of living from and on the mountain landscape. This knowledge is dependent on an intimate and direct connection with the world and the flora and fauna that live in it. This intimacy enables a comprehensive understanding of the local environment. It illustrates the contextual relationship between cultural use and plant diversity (Kassam 2009b).

\section{Conclusion}

Indigenous peoples of the Pamirs have maintained knowledge of a multiplicity of medicinal plants through periods of socio-cultural and ecological change. Villagers know
Fig. 3 Seasonal availability of gathered and cultivated medicinal plants

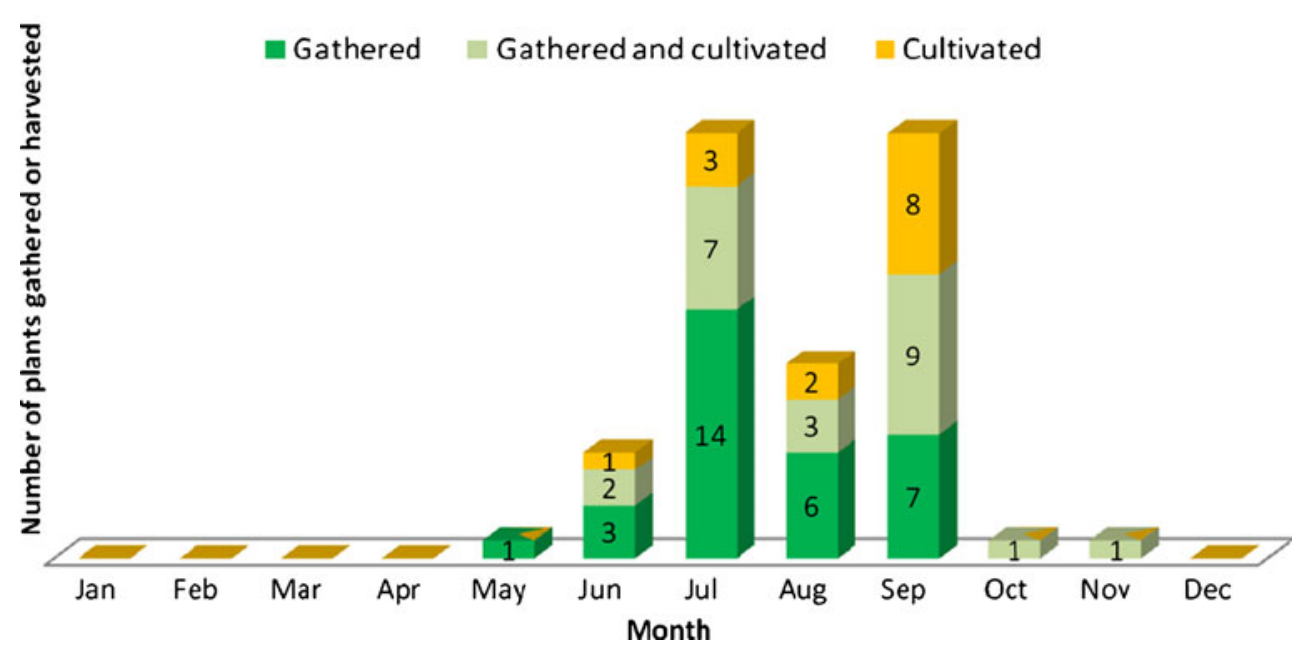


Fig. 4 Part of plant used for medicinal purposes

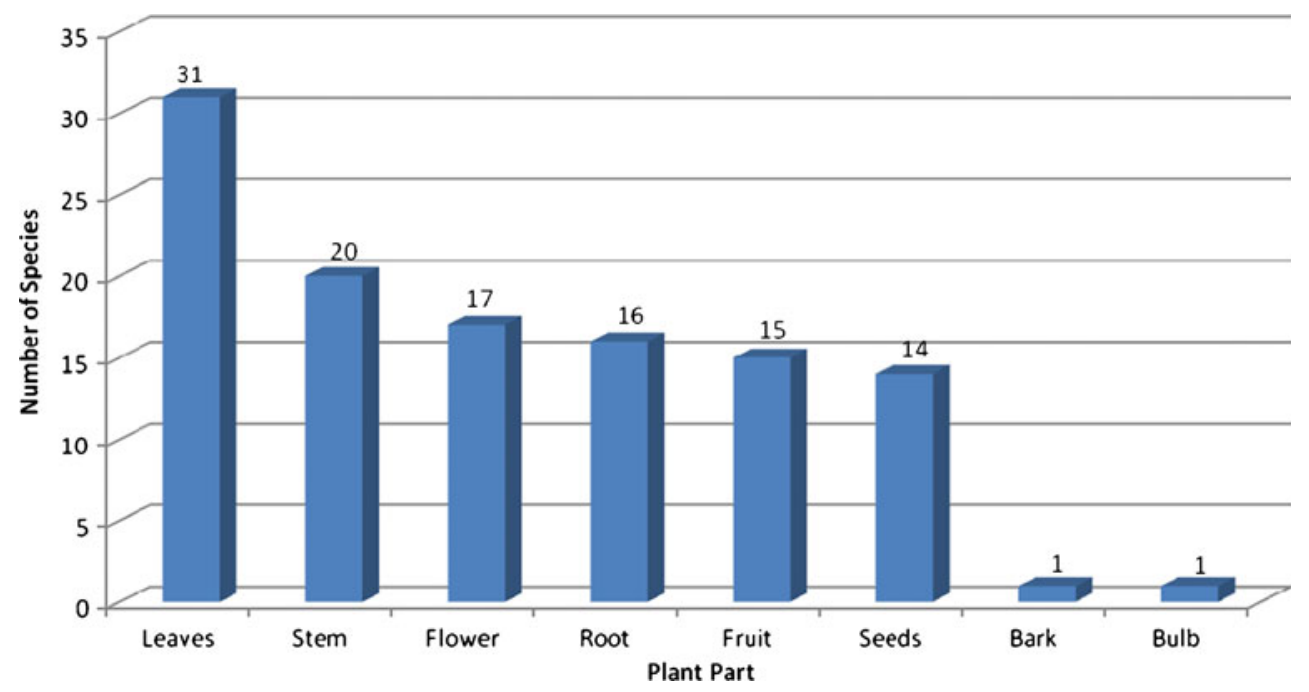

how to use plants to address the most common causes of hospitalization. Medicinal plants, therefore, contribute to health sovereignty by providing important health care options. The notion that 'food is medicine' can inform a culturally relevant approach to health care in the Pamirs. In a region where malnutrition and diet-related diseases are epidemic, this is a particularly significant socio-cultural and ecological asset. The ability to preserve medicinal plants through the times when they are unavailable plays a key role in the health sovereignty of Pamiri peoples. Stores of medicinal plants may be a drawn upon for treatments during winter months, unusual growing seasons, as well as periods of instability and war.

While medicinal plants are an important source of health sovereignty, they may not be sufficient. For instance, tuberculosis and maternal mortality are serious problems in Afghan Badakhshan (Smith and Burnham 2005; WHO

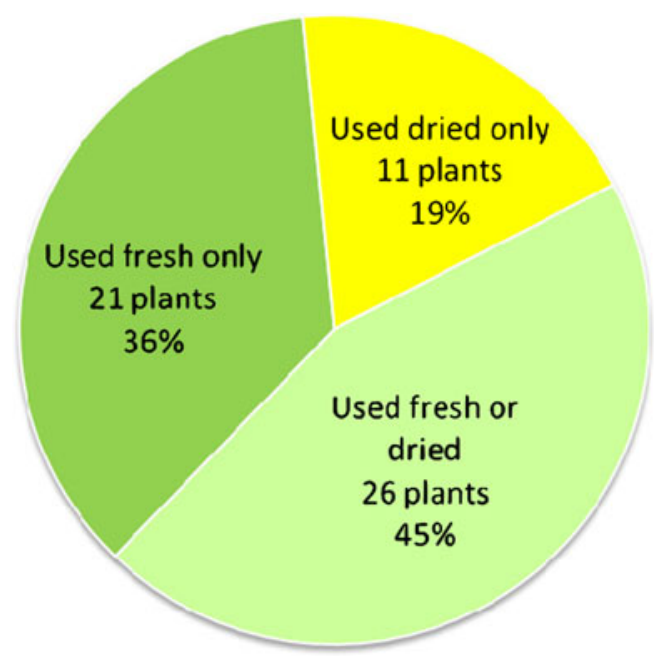

Fig. 5 Use of medicinal plants as fresh and/or dried
2009) and may not be treatable using plants alone. In emphasizing the significance of medicinal plants, we do not privilege one kind of health care over another; different types of treatment are appropriate or necessary in different contexts (Byg et al. 2010). We are simply suggesting that health sovereignty comes from the ability to make choices about medical care, especially under conditions of uncertainty.

Medicinal plant knowledge is historically part of the socio-cultural and ecological fabric of the peoples of the Pamirs. A significant portion of this historical information

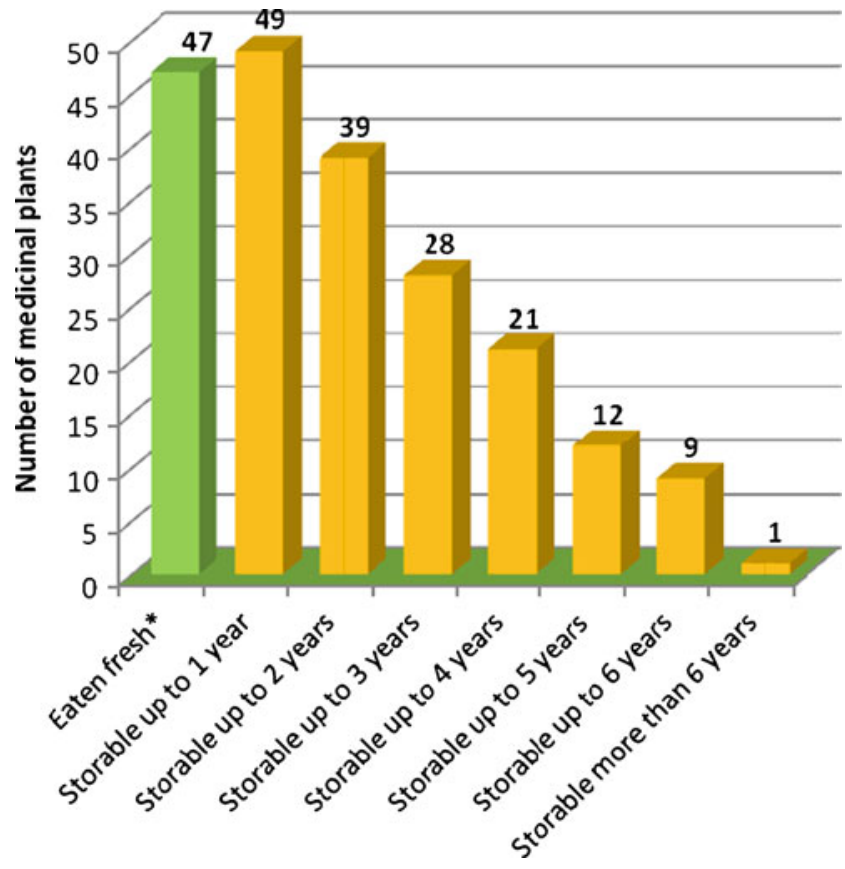

* 11 plants are used only when dried and are not included in this category.

Fig. 6 Maximum storage times for medicinal plants 


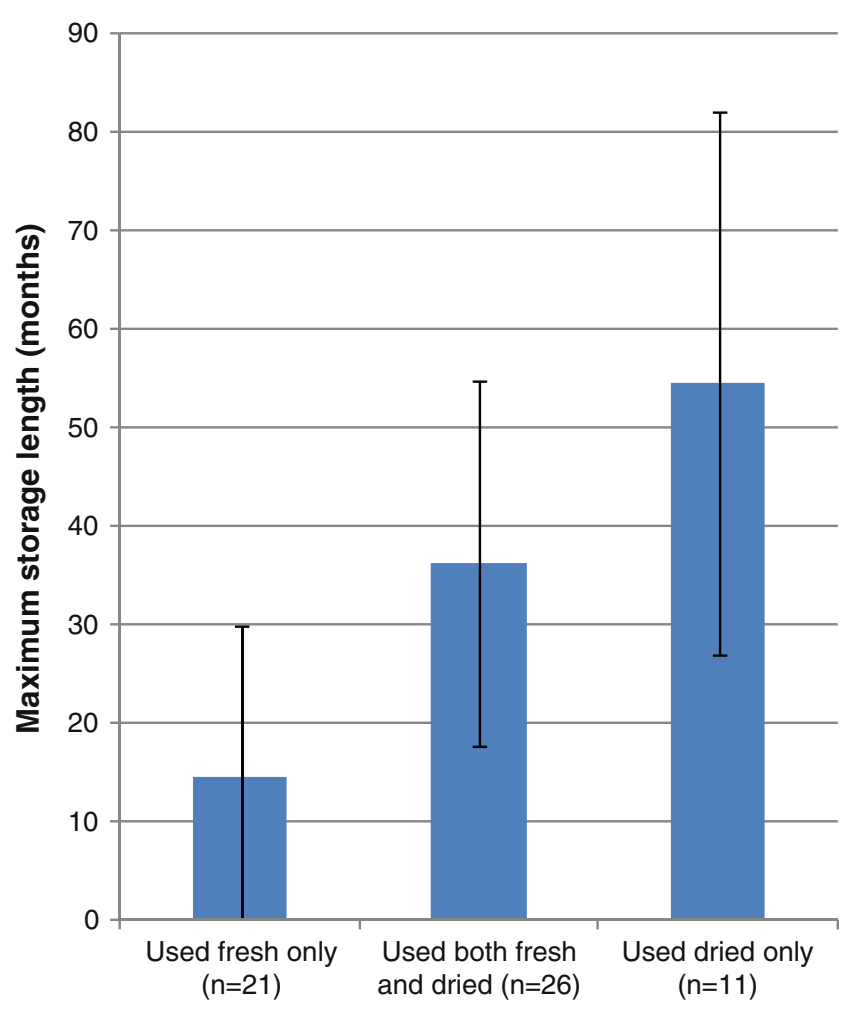

Fig. 7 Maximum storage time of medicinal plants as compared to use

in manuscripts, which are in Persian and other local languages, remain extant but not widely accessible. It is important that in situ centers of learning, such as the University of Central Asia, work with civil society organizations and individuals to engage the relevance of these banks of knowledge meaningfully and respectfully in their curriculum for undergraduate and graduate education, thus situating their research in the communities where they are located.

As medicinal plant use is context specific, there may be differences in use between people with different ecological professions, such as pastoralists and agriculturalists. Furthermore, there is opportunity to examine differentiated medicinal plant uses by ethnicities, elevation, and valleys of the Pamir Mountains of Afghanistan and Tajikistan. In other mountainous regions of Central Asia, considerable research has been undertaken on medicinal plant trade (Byg et al. 2010; Kala 2005; Olsen 1998; Salick et al. 2006). In the Pamirs, it is also necessary to explore which medicinal plants are traded in local markets or for exports (regional/ international) and for what uses. This latter research will also add to greater practical understanding of health sovereignty as well as sustainability of medicinal plant harvesting. Although we found evidence of sustainable practices, this dimension requires further detailed research. It is important to keep in mind, that the ideas of sustainability and sovereignty, while distinct, are mutually reinforcing.
Indigenous knowledge of medicinal plants in the Pamirs is fundamentally dependent on its use. Knowledge of medicinal plants is not only embedded in people's minds but in their relations within their habitat. This knowledge is critical to the adaptation and resilience of these communities under conditions of socio-cultural and environmental change.

Acknowledgements The analysis and discussion contained within this article would not have been possible without the contribution of knowledge from the villagers in the Pamir Mountains of Afghanistan and Tajikistan. This research was funded by a grant from the Christensen Fund. The University of Central Asia was a base of operations and provided logistical support. Research activities were facilitated by the Mountain Societies Development Support Programme (MSDSP) in Tajikistan, and with the assistance of Aga Khan Foundation in Afghanistan. Valuable advice was provided by various members of the Academy of Sciences of the Republic of Tajikistan and specifically the Pamir Biological Institute. Umed Bulbulshoev and Janelle Burke, respectively, helped verify local and botanical names of plants. Phoenix Paz assisted in compiling data for analysis. We are grateful to the anonymous reviewers for their valuable suggestions and comments.

Open Access This article is distributed under the terms of the Creative Commons Attribution Noncommercial License which permits any noncommercial use, distribution, and reproduction in any medium, provided the original author(s) and source are credited.

\section{References}

AKF-T [Aga Khan Foundation, Tajikistan] (2004). Patient Contributions To and Attitudes on Paying for Health Care in GornoBadakhshan Autonomous Oblast, Republic of Tajikistan. AKF Tajikistan and Health Management and Information Systems, Dushanbe.

AKF-T [Aga Khan Foundation, Tajikistan] (2008). Health and Nutrition Survey 2007: Gorno-Badakhshan, Oblast. Evaluation and Learning Unit, AKF Tajikistan, Dushanbe.

Bartlett, L., Mawji, A. S., Whitehead, S., Crouse, C., Dalil, S., Ionete, D., Salama, P., and the Afghan Maternal Mortality Study Team (2005). Where giving birth is a forecast of death: maternal mortality in four districts of Afghanistan, 1999-2002. The Lancet 365(9462): 864-870.

Boesi, A., and Cardi, F. (2006). The Selection Process of the Materia Medica: The Approach of a Tibetan Practitioner in the Region of Dhorpatan (Nepal). Rivista Degli Studi Orientali 79: 47-64.

Butler, L. M., Dephelps, C., and Howell, R. E. (1995). Focus Groups: A Tool for Understanding Community Perceptions and Experiences. Western Regional Extension Publication No. WREP0128, Seattle.

Byg, A., Salick, J., and Law, W. (2010). Medicinal Plant Knowledge Among Lay People in Five Eastern Tibet Villages. Human Ecology 38(2): 177-191.

Chapin III, F. S., Peterson, G., Berkes, F., Callaghan, T., Angelstam, P., Apps, M., Beier, C., Bergeron, Y., Crepin, A. S., Danell, K., Elmqvist, T., Folke, C., Forbes, B., Fresco, N., Juday, G., Niemela, J., Shvidenko, A., and Whiteman, G. (2004). Resilience and vulnerability of northern regions to social and environmental change. Ambio 33(6): 344-349. 
Etkin, N. L. (2003). Co-evolution of people, plants, and parasites: biological and cultural adaptations to malaria. Proceedings of the Nutrition Society 62(2): 311-317.

Etkin, N. L., and Ross, P. J. (1982). Food as Medicine and Medicine as Food: An adaptive framework for the interpretation of plant utilization among the Hausa of northern Nigeria. Social Science \& Medicine 16(17): 1559-1573.

Etkin, N. L., and Ross, P. J. (1994). Pharmalogic Implications of "Wild" Plants in Hausa Diet. In Etkin, N. (ed) Eating on the Wild Side. University of Arizona Press, Tucson, pp. 85-101.

Eurasianet.org (2008). Tajikistan: Government Shakes Down Population Amid Deepening Economic Dysfunction. Published May 6, 2008. [Online] URL: http://www.eurasianet.org/departments/ insight/articles/eav050708.shtml (Accessed July 1, 2010).

Folke, C. (2006). Resilience: The emergence of a perspective for social-ecological systems analyses. Global Environmental Change 16(3): 253-267.

Folke, C., Carpenter, S., Elmqvist, T., Gunderson, L., Holling, C. S., and Walker, B. (2002). Resilience and sustainable development: Building adaptive capacity in a world of transformations. Ambio 31(5): 437-440.

Gibbs, A. (2003). Focus groups. Social Research Update 19. [Online] URL: http://www.soc.surrey.ac.uk/sru/SRU19.html (Accessed August 17, 2003).

Губанова, И. А., Киселёва, К. В., и Новиков, В. С. (1987). Дикорастущие полезные растения. Издательсво московского университета, Москва.

Holling, C. S. (1973). Resilience and stability of ecological systems. Annual Review of Ecology and Systematics 4: 1-23.

Hooper, D. (1937). Useful Plants and Drugs of Iran and Iraq. Field Museum of Natural History, Chicago.

Kala, C. P. (2005). Indigenous Uses, Population Density, and Conservation of Threatened Medicinal Plants in Protected Areas of the Indian Himalayas. Conservation Biology 19(2): 368-378.

Kassam, K.-A. (2009a). Viewing Change Through the Prism of Indigenous Human Ecology: Findings from the Afghan and Tajik Pamirs. Human Ecology 37(6): 377-390.

Kassam, K.-A. (2009b). Biocultural Diversity and Indigenous Ways of Knowing: Human Ecology in the Arctic. University of Calgary Press, Calgary.

Kassam, K.-A. (2010). Pluralism, Resilience, and the Ecology of Survival: Case Studies from the Pamir Mountains of Afghanistan. Ecology and Society 15(2): 8.

Kickbusch, I. (2000). The Development of International Health Policies-Accountability Intact? Social Science \& Medicine: 51 (6): 979-989.

Кисляков, Н. А. и Писарчик, А. К. (1970). Таджики Кратегина и Дарваза. Академия Наук Таджикской ССР. Институт Истории им. А. Д. Дониша. Выпуск 2. Дониш, Душанбе.

LaDuke, W. (2005). Recovering the Sacred: The Power of Naming and Claiming. South End Press, Cambridge.

LaDuke, W., Brown, F., Kennedy, N., Reed, T., Warner, L., and Keller, A. (2010). Sustainable Tribal Economies: A Guide to Restoring Energy and Food to Native America. Honor the Earth, Minneapolis.

Miller, T., Baird, T. D., Littlefield, C. M., Kofinas, G., Chapin, III, F. S., and Redman, C. (2008). Epistemological pluralism: Reorganizing interdisciplinary research. Ecology and Society 13(2): 46. [online] URL: http://www.ecologyandsociety.org/vol13/iss2/art46/.

Moerman, D. E. (1998). Native American Ethnobotany. Timber Press, Portland, Oregon.

Mousseau, F. (2005). Food aid or food sovereignty? Oakland Institute, Oakland, California.

Nabhan, G. P. (2009). Where our food comes from: Retracing Nikolay Vavilov's Quest to End Famine. Island Press, Washington, DC.
Наврузшоев, Д. (1998). Конспект флоры бассейна реки Бартанг (Западный Памир). Памирский Биологический Институт им. Х.Ю.Юсуфбеков. Академии Наук Республики Таджкистан. Ботанический институт им. В.Л. Комарова. Российская Академия Наук Санкт-Петербург. НЕСТОР, Санкт-Петербург.

Нуралиев, Ю. (1989). Лекарственные растения. Выпуск 2. Маориф, Душанбе.

OED [Oxford English Dictionary Online] (2010). Medicine. Published September 2010. [Online] URL: http://dictionary.oed.com/cgi/ entry $/ 00304560$ ?query type $=$ word $\&$ queryword $=$ medicine $\&$ first $=1 \&$ max_to _show $=10 \&$ sort_type $=$ alpha\&search $\_i d=1$ unzgnv4kW-7411\&result_place=1 (Accessed September 16, 2010).

Olsen, C. S. (1998). The Trade in Medicinal and Aromatic Plants from Central Nepal to Northern India. Economic Botany 52(3): 279292.

Patwardhan, B., Warude, D., Pushpangadan, P., and Bhatt, N. (2005). Ayurveda and Traditional Chinese Medicine: A Comparative Overview. Oxford University Press, London.

Patwardhan, B., and Mashelkar R. A. (2009). Traditional medicineinspired approaches to drug discovery: can Ayurveda show the way forward? Drug Discovery Today 14(15): $804-811$.

Rerkasem, K., Yimyam, N., Korsamphan, C., Thong-Ngam, C., and Rerkasem, B. (2002). Agrodiversity Lessons in Mountain Land Management. Mountain Research and Development 22(1): 4-9.

Salick, J., Byg, A., Amend, A., Gunn, B., Law, W., and Schmidt, H. (2006). Tibetan Medicine Plurality. Economic Botany 60(3): 227-253.

Sezik, E., Yesilada, E., Shadidoyatov, H., Kulivey, Z., Nigmatullaev, A. M., Aripov, H. N., Takaishi, Y., Takeda, Y., and Honda, G. (2004). Folk medicine in Uzbekistan I. Toshkent, Djizzax, and Samarqand provinces. Journal of Ethnopharmacology 92(2-3): 197-207.

Shankar, D. (2001). Agenda for Revitalization of Indian Medical Heritage. Voluntary Health Association of India, New Delhi.

Shankar, D., Unnikrishnan, P. M., and Venkatasubramanian, P. (2007). Need to develop inter-cultural standards for quality, safety and efficacy of traditional Indian systems of medicine. Current Science 92(11): $1499-1505$.

Shukla, S., and Gardner, J. (2006). Local knowledge in communitybased approaches to medicinal plant conservation: Lessons from India. Journal of Ethnobiology and Ethnomedicine 2(20): 1-9. [online] URL: http://www.ethnobiomed.com/content/2/1/20.

Shukla, S., and Sinclair, A. J. (2009). Becoming a traditional medicinal plant healer: divergent views of practicing and young healers on traditional medicinal plant knowledge skills in India. Ethnobotany Research and Applications, 7, 39-51. [online] URL: http://www.ethnobotanyjournal.org/vol7/i1547-3465-07-039.pdf (Accessed Sept. 16, 2010).

Smith, R. (2006). Trade in health services: current challenges and future prospects of globalization. In Jones, A. M. (ed.), The Elgar Companion to Health Economics. Edward Elgar Publishing, Northampton.

Smith, J. M., and Burnham, G. (2005). Conceiving and dying in Afghanistan. The Lancet 365: 829-830.

Соколов, С. Я., и Замотаев, И. П. (1984). Справичник по лекарственным растениям (Фитотерапия). Медицина, Москва.

Sundriyal, M., and Sundriyal, R. C. (2001). Wild Edible Plants the Sikkim Himalaya: Nutritive Values of Selected Species. Economic Botany 55(3): 377-390.

United Nations (2008). United Nations Declaration on the Rights of Indigenous Peoples. [online] URL: http://www.un.org/esa/socdev/ unpfii/documents/DRIPS_en.pdf (Accessed Sept 16, 2010).

Vavilov, N. I. (1926). Studies in the Origin of Cultivated Plants. Institut de Botanique Appliquée et d'Amélioration des Plantes, Leningrad.

Vavilov, N. I. (1951). The Origin, Variation, Immunity and Breeding of Cultivated Plants: Selected Writings (Translated by K. Starr Chester). Chronica Botanica, Waltham.

Vavilov, N. I. (1957). World Resources of Cereals, Leguminous Seed Crops and Flax, and Their Utilization in Plant Breeding 
(Translated by Marc Paenson and Z. S. Cole). The Academy of Sciences of the USSR, Moscow.

Vavilov, N. I. (1992). Origin and Geography of Cultivated Plants (Translated by Doris Löve). University of Cambridge Press, Cambridge.

Vavilov, N. I. (1997). Five Continents. The International Plant Genetic Resources Institute, Rome.

Voeks, R., and Leony, A. (2004). Forgetting the Forest: Assessing Medicinal Plant Erosion in Eastern Brazil. Economic Botany 58 (Supplement): 294-306.

Walker, B. H., and Salt, D. A. (2006). Resilience Thinking: Sustaining Ecosystems and People in a Changing World. Island Press, Washington, DC.
WHO [World Health Organization] (2002). WHO Traditional Medicine Strategy 2002-2005. World Health Organization, Geneva.

WHO [World Health Organization] (2009). Global Tuberculosis Control: Epidemiology, Strategy, Financing. World Health Organization, Geneva.

Windfuhr, M., and Jonsén, J. (2005). Food Sovereignty: Towards democracy in localized food systems. ITDG Publishing, Rugby, UK. [online] URL: http://www.ukabc.org/foodsovereignty_itdg fian_print.pdf (Accessed Sept. 16, 2010).

Wyndham, F. S. (2010). Environments of Learning: Rarámuri Children's Plant Knowledge and Experience of Schooling, Family, and Landscapes in the Sierra Tarahumara, Mexico. Human Ecology 38(1): 87-99. 